\title{
CYBERPUNK SCIENCE FICTION AND POSTMODERN AESTHETICS: A CRITICAL APPROACH
}

\author{
Metin ÇOLAKa
}

\begin{abstract}
Postmodern theory and aesthetics have become a frequently discussed phenomenon in almost every field, especially since the 1980s. However, this theory and aesthetics appear with a significant effect, especially in the field of literature and art. Cinema has a special place here. Postmodern aesthetics still maintains its existence by increasing its effectiveness in cinema. One of the factors that put this aesthetic in the focus of current discussions is undoubtedly the contributions of science fiction genre, which has increased its effectiveness and popularity with technology, to this aesthetics. Science fiction literature is a field that offers tools to postmodern aesthetics that can approach the existing system both critically and affirmatively. However, science fiction literature, as a whole, does not do this, cyberpunk as a subgenre within this field does this: cyberpunk provides texts, perspectives to postmodern aesthetics for criticizing the system, or the establishment. But how critical are these critical perspectives? Does this subgenre really criticize the system in which it was born, or does it subtly glorify it? In this study, the answers to these questions are tried to be given based on the critical thoughts of very important writers of the Western world, Fredric Jameson and György Lukacs. Since science fiction and its subgenre cyberpunk are such a wide field, this study focuses only on William Gibson and Bruce Sterling, who played a decisive role in the emergence and popularization of this subgenre and examined the characteristic features of the dystopian background of this subgenre using the descriptive research methodology. This study differs from previous studies as it deals with the contributions of Gibson and Sterling to postmodern aesthetics through the critical perspectives of Lukacs and Jameson.
\end{abstract}

Keywords: Science fiction, Literature, Art, Cyberpunk, Postmodernism

$$
\text { 旅淡 }
$$

\section{SİBER PUNK BİLIM KURGU VE POSTMODERN ESTETIK: ELEŞTIREL BİR YAKLAŞIM Özet}

Postmodern kuram ve estetik özellikle 1980'li yıllardan bu yana hemen her alanda sıkça tartışılan bir olgu haline gelmiştir. Ancak bu kuram ve estetik özellikle edebiyat ve sanat alanında belirgin bir etkiyle karşımıza çıkar. Burada sinema özel bir yere sahiptir. Postmodern estetik sinemada etkinliğini arttırarak bugün hala varlığını korumaktadır. Bu estetiği güçlü bir şekilde güncel tartışmaların odağına oturtan etmenlerden biri kuşkusuz teknolojiyle birlikte etkinliği ve popülaritesi artan bilim kurgu türünün bu estetiğe yapmış olduğu katkılardır. Bilim kurgu edebiyatı postmodern estetiğe, varolan sisteme hem eleştirel hem de olumlayıcı

\footnotetext{
a Doç. Dr., Ege Üniversitesi, Güzel Sanatlar, Tasarım ve Mimarlık Fakültesi, Görsel İletişim Tasarımı Bölümü, colak.metin@ege.edu.tr

Makale Geliş Tarihi: 25.10.2021, Makale Kabul Tarihi: 03.12.2021
} 
anlamda yaklaşabilen araçlar sunan bir alandır. Ancak bir bütün olarak bilim kurgu edebiyatı bunu yapmaz, bu alanın içerisinde bir alt tür olarak siber punk bunu yapar: Siber punk postmodern estetiğe sistemi eleştiren metinler, perspektifler sağlar. Ancak bu eleştirel perspektifler ne kadar eleştireldir? Bu alt tür gerçekten içinde doğduğu sistemi eleştirmekte midir, yoksa onu alttan alta yüceltmekte midir? Bu soruların cevabı bu çalışmada Fredric Jameson ve György Lukacs gibi Batı dünyasının çok önemli yazarlarının eleştirel düşüncelerinden yola çıkılarak verilmeye çalışılmaktadır. Çalıma, bilim kurgu ve onun alt türü siber punk çok geniş bir alan olduğundan ötürü, bu alt türün ortaya çıkışında ve popüler hale gelişinde belirleyici rol oynayan sadece William Gibson ve Bruce Sterling'e odaklanmakta, bu alt türün distopik arka planının karakteristik özellikleri tanımlayıcı araştırma yöntemi kullanılarak incelemektedir. Bu çalışma Gibson ve Sterling'in postmodern estetiğe yaptığı katkıları Lukacs ve Jameson'ın eleştirel perspektifleri aracılığıyla ele aldığı için daha önceki çalışmalardan farklılaşmaktadır.

Anahtar Kelimeler: Bilim kurgu, Edebiyat, Sanat, Siberpunk, Postmodernizm

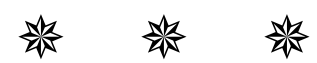

\section{Introduction}

So far, important studies have been done on the elements of postmodern aesthetics. Undoubtedly, the foremost among these is Ihab Hassan's (1983) work called 'The Dismemberment of Orpheus'. It is understood that the works of Hassan and others limited the term to the literary-architectural field and did not show the same interest or desire to approach other fields. Although there are studies on what kind of framework postmodern aesthetics is structured in other fields (the first important works that come to mind are Harvey's (1992) and Connor's (1997) works, of course), none of these works focus on the contributions of cyberpunk to postmodern aesthetics at the desired level. Cyberpunk is only considered as a category, as a sub-genre of science fiction, within the framework of its contributions to postmodern aesthetics. However, cyberpunk should be examined as a separate and important field, as it has developed a style that takes postmodern aesthetics to its centre.

Postmodern aesthetics has gained a solid place especially in the field of cyberpunk. Postmodernism or postmodern thought has gained a much more prominent and ideological appearance with the rise of the cyberpunk subgenre in the field of science fiction. There are undoubtedly socio-cultural and political reasons why cyberpunk became popular and influential in the 1960s and 70s. These reasons can be extended to technological phenomena, even computer technologies and globalisation. All these reasons have popularised cyberpunk, a subgenre of science fiction.

In this study, cyberpunk, and its relations with postmodern aesthetics, which came to the fore in the 1960s and 1970s and whose effectiveness continued to increase in the following decades (especially in the field of cinema), will be discussed. In this context, the emergence and development of cyberpunk, especially the contributions of two important figures, William Gibson, and Bruce Sterling, to the genre, the dystopian background of it, its interactions with postmodern aesthetics are examined in a critical perspective using descriptive research methodology.

When examining the connections of cyberpunk and the work of William Gibson and Bruce Sterling with postmodern aesthetics, I will draw on anti-postmodern theorists such as Fredric Jameson (1974, 
1991, 1998) and Jürgen Habermas (1987), but Jameson significantly. In the final analysis, postmodern aesthetics and cyberpunk are related to the transformations experienced in the period we live in. Breaks that occur at the macro level also affect the visions and perspectives of works in the literary-aesthetic field. I will deal with these breaks by making use of the theses of the Hungarian theorist György Lukacs $(1969,1974)$ on contemporary society and the image of man within this society.

\section{A. THE ORIGIN AND DEVELOPMENT OF THE TERM, 'CYBERPUNK'}

The term 'cyberpunk' was used for the first time in Bruce Bethke's short story called "Cyberpunk".1 This short story was written in the spring of 1980, but it was published in the journal 'Amazing Science Fiction Stories' in 1983. It seems appropriate to accept the term 1983 as the birth year of 'cyberpunk'.2 Bethke's purpose was to find a new and striking term that can reflect the punk attitude in the civilization which continuously changes with the advancement of technology. Bethke (2021a) writes on how he coined the term:

"How did I actually create the word? The way any new word comes into being, I guess through synthesis. I look a handful of roots -cyber, techno, et al-mixed them up with a bunch of terms for socially misdirected youth and tried out the various combinations until one just plain sounded right."

The term 'cyberpunk', after the interesting invention of Bethke, was started to be used by influential authors, such as William Gibson, Bruce Sterling, John Shirley, Rudy Rucker, John Shirley, Rudy Rucker, Micheal Swanwick, Pat Cadigan, Lewis Shiner, Richard Kadrey, Watte John Williams, and Greg Bear.

Larry McCaffery (1993a, p. 9-10) states, in his illuminative work, that the leading avantgarde writers such as Alfred Bester, William S. Burroughs, J.G. Ballard, Philip K. Dick and Thomas Pynchon significantly contributed to the rise of cyberpunk literature and cinema in the 1980s. These authors, according to McCaffery (1993a, p. 5), not only have a significant role in cyberpunk science fiction literature, but also in the rise of the postmodern thought. Therefore, unlike the understanding of classical science fiction, we need to evaluate the most articulated subgenres with postmodern thinking McCaffery (1993a, p.5). Richard Kadrey and Larry McCaffery (1993), in their detailed studies on the genre, classify the developments in a historical continuity that shaped the ideology and aesthetics of cyberpunk science fiction. This classification starts with Mary Shelly's cult literary work "Frankenstein" (1818), goes to Raymond Chandler's “The Big Sleep” (1939), Anthony Burgess' “A Clockwork Orange” (1962), Thomas

\footnotetext{
${ }^{1}$ On the other hand, in the interesting study of Timothy Leary (1993, p. 247), it is suggested that the term 'cyberpunk' is old Greek origin. According to Leary, the origin of the term 'Cyberpunk', 'Cybernetics' is derived from the word Kubernetes which means 'pilot' in ancient Greek. Hellenic civilization had caught a highly advanced level of sophistication due to geographical conditions. In those days, the marines could be opened to the sea in days, where they do not have the material to find directions such as the map. "Athenian cyberpunk, the pilot, decisions about the sea itself." This real situation has contributed to the development of an individual confidence in the ancient Greek civilization, which provided a kind of survival motivation that allows you to be stripped of all conventional thoughts when necessary. Leary stresses that this condition has also made great contributions to the development of democracy understanding, as well as religious humanism based on freedom, pagan entertainment, and speculative thoughts in this civilization.

2 Bethke (2021) states on his own website that he did not take the term 'cyberpunk' within the framework that it is used in current cyberpunk literature. Bethke (2021b) underlines that William Gibson was the person who first used the term 'cyberpunk' in today's sense.
} 
Pynchon's “The Crying Lot 49” (1966), Philip K. Dick's “Do Androids Dream of Electric Sheep" (1968), Jean-François Lyotard's "Postmodern Condition" (1979), Ridley Scott's Blade Runner (1982), and ends with Arthur Kroker and David Cook's "The Postmodern Scene: Excremental Culture and HyperAesthetics" (1986), and Mark Leyner's interesting work "My Cousin, My Gastroenterologist" (1990). Other important works, films like Robert Longo's Johnny Mnemonic (1995), and The Wachowskis' The Matrix series $(1999,2003)$ were not included in their book, due to the publication year. There is little doubt that all these studies have made the rise of cyberpunk in the 1980s.

The basic characteristic features of the type of science fiction belonging to chronologically modernist era have radically changed with the rise of cyberpunk. The most important break is related to the concept of technology. Classic or semi-modern science fiction has a certain utopic perspective even when criticizing technological cases by catching technology from a positive perspective in the final analysis. However, cyberpunk science fiction criticizes this modernist technological optimism and acquires a dense dystopic appearance by associating its processes with social decay. As such a radical change in perspectives occurs the subject matters of the stories begin to concentrate on the negative views of the new technological civilization, such as nihilism, sensual metamorphosis, devastating sex, cloning, virtual reality, disruptive sex, anarchism, and hacking.

Cyberpunk, in its essence, describes this technological civilization or 'technologically overdeveloped civilization' with bad views and the concepts which have long been known as the views and concepts of high art or philosophy. In this view, the language of philosophy and high art is blended with the practical language of technological civilization. McHale (1993, p.309). stresses that the philosophy of cyberpunk came across when the difference between high, formal art and low, mass culture art collapsed. With the collapse of the distinctions between the two layers, the meanings, the products, liking or thought of high art systematics come together with popular cases; high art meets with punk, rap, techno, and underground music culture. It is not surprising that after this collapse images and meanings of nihilism, anarchism, sensual metamorphosis, cloning, virtual reality, dystopic visions, etc. began to dominate cultural spheres. At this point, both an influential false belief which claims a deep pessimism about the future of humanity, and a distorted image of reality are born. The thoughts like the "welcome to the desert of the real" (The Matrix opening motto) become available here (McCaffery (1993a, p. 9). In this situation, the world, the reality is just as a view of the nuclear disaster. This type of dystopic visions associate technology with the loss of reality.

This generation of cyberpunks, which is not fascinated with satellite technologies, video and audio players, computers and computer games, digital video tools, is the first generation which takes all these forms as the matrix, natural developments of daily life (McCaffery, 1993a, p. 9). This generation tried to respond to the technological cases and change social reality with the aesthetic forms of the counterculture

| 1628 | (McCaffery, 1993a, p. 9). As McCaffrey (1993a, p. 13-14). has indicated that cyberpunk was inevitably returned to Pynchon, Ballard, Dick, and Burroughs' avantgarde science fiction tradition in order to ensure its own counter-stance. Cyberpunk has taken over the basic perspectives of this tradition and face them social decay caused by technological civilisation. Through these perspectives, a discourse that reflects an assembled punk aesthetics was developed. This discourse is an eclectic discourse that leans 
on the above literary tradition, as well as the imagery of contemporary society, drug culture products, Punk Rock, 'Heavy Metal Funny Books'.

This type of discourse is extensively and efficiently used in the canonical texts of the genre, like in William Gibson's “Neuromancer" (1993), "Count Zero" (1986), "Monalisa Overdrive” (1988) and in Bruce Sterling's "Schismatrix" (1985). Here, Neuromancer is required to position a different point. It carries the feature of being the archetype of cyberpunk literature. Neuromancer specifies the terminology of cyberpunk, and it uses the concepts, like 'cyberspace' and 'virtual reality' for the first time within the genre. The discourse, concepts, and styles developed in this work were taken further dimensions in other canonical texts of the genre, Count Zero and Monalisa Overdrive. These masterpieces of cyberpunk science fiction literature built on this Gibson's Neuromancer.

Cyberpunk indicates that we should not focus on the possibilities of science, but possible hazards of it in our contemporary society. It approaches technology with suspicion using the subject matters, such as cosmetic surgery, cloning, artificial intelligence, nuclear, biological, and chemical weapons, genetic engineering and associates them a scientific disaster scenario. According to the basic criticism of cyberpunk, "all things to mice can be made to people" (Sterling, 2021). Therefore, the human can also be transformed into a machine, a replica, to goods. Cyberpunk tries to reflect the truth as is, attempts to reveal it with all dystopic views (Sterling, 2021). In this genre, characters are mostly marginal, and they feel alien to the society and time they live in. They live on the edge of the society and perceive the future with a dystopian perspective without any expectation of the future.

\section{B. WILLIAM GIBSON AND BRUCE STERLING}

In the middle of the 1980s, technology reaches a dominant position in almost every area of life. Although computer technologies are on a large scale, they did not determine every sphere in society yet. In particular, the developments in communication, medical and space sciences begin to be effective in every aspect of life in this period. A critical science fiction literature was founded by influential authors such as J. Ballard, T. Pynchon, and Philip K. Dick of the decade. This tradition also shaped the basic perspectives of cyberpunk science fiction literature. Besides this, other important developments on the macro scale in the 1980s, like transformations of the internal dynamics of capitalism and formation of transnational, multicultural companies on the world scale, structured the essence of the genre. This period is a historical period where all the evaluations of Mandel (1980) are reflected in the late capitalism phase. In addition to all these social and technological realities, another case which is effective in the rise of science fiction is the aesthetic perceptions and political demands of punk and subculture groups. The control of the giant multinational companies, unnecessary technological sophistication, extreme level of fragmentations in society, and punk aesthetics... All these facts, compared to other cyberpunk writers, were synthesised in a more philosophical and sophisticated literary style in the oeuvre of William Gibson. Gibson, as Darko Suvin (1993, p. 352) underlines, "brings science fiction a new electronic punk sensitivity". His first important work, Neuromancer, is like a synthesis of poetry, popular culture, and technology in this context (McCaffrey, 1993b, p.264). All cases characterizing contemporary life (fragmentation, extreme technological sophistication, strength of multinational companies, power of computer technologies, cloning, etc.) is treated with a critical approach in Gibson's works. His characters, 
as Suvin (1993, p. 264) has correctly observed, are fifteen to thirty-aged people who are most open to popular culture imagery and technological determination. The real factor that shaped this generation was late capitalism which filled all the cultural gaps of this historical period. As the developments in socio-cultural and technological spheres have become disappointing, the quest and the forms of expressions of the generation have become more bohemian and more metaphorical. Neuromancer is one of the best examples of this disappointment and language (McCaffrey, 1993b, p. 269-70). At this point a question arises: How and why a metaphorical language is used in such a disappointment? The reason for this is undoubtedly a wish to talk about the current, to criticise it within radical perspectives. In order to speak today such a language is compulsory and certain emblematic metaphors are used. This metaphoric language comes up with human-machine human (android) contrast in 2019 Los Angeles which is dominated by multinational capitalist companies in Philip K. Dick's “Do Androids Dream of Electric Sheep" (1999). This language passes through three different cities and places in Gibson's work ${ }^{3}$, Neuromancer - three separate cities and venues, Chiba City, Istanbul, and Paris- and structured in the experiences of 'Console Cowboy', and in a drug addict, a cyberspace hacker, an anti-hero, the cyberpunk's prototype character, Case (Henry Dorsett Case) who travel in the world of computer matrix. Similarly, Johnny Mnemonic (Gibson, 1995) uses a highly metaphoric language and tells the dramatic story of a courier who has a chip that has been placed in his brain and to drain his childhood memories that were reserved there. In the story, Johnny can double the capacity of $80 \mathrm{~GB}$ as soon as he deleted his childhood memories. This situation of Johnny presents us a dystopic vision of humanity in an unsafe world. The technological paranoia, another common feature of the literature, is moved to the extreme limits here.

Gibson's other own concepts, especially the 'cyber space' and 'virtual reality', found an extensive use and caused debates after the second half of the 1990s. Gibson coined these terms for the first time in the decade. In an interview where he clarifies how he developed the term, 'cyberspace', Gibson explains that he coined the term while he was synthesising human experience with the screen and teleportation techniques frequently used Pynchon's novels (McCaffrey, 1993b, p. 272). Teleportation requires the relationship between body and a different space. According to Gibson, the computer screen also indicates that a certain spatial extension exists in its own. When we look at the computer screen, we go to its space, a virtual, or "real" (Gibson prefers this word) space (McCaffrey, 1993b, p. 272). Therefore, according to Gibson, there is always a second space beyond what we see. Gibson's idea has found a common usage, especially with the development of computer technologies, and started to be intensively discussed in the following decades.

| 1630 | 3 Bruce Sterling (1998) in his introduction to "Mirrorshades" which is regarded as the 'magnum opus' of cyberpunk literature, has noted that this division, being in different places at the same time, is a common feature of all recent cyberpunk literature. Sterling emphasizes that with the rise of globalisation in the 1980s, the cyberpunk entered a new phase where it searches a larger perspective that covers effects of this phenomenon. The influence of this situation on the cyberpunk imagery became obvious soon. This imagery reflected in Gibson's Neuromancer with three different cities and venues, in Lewis Shiner's Frontera (1984) with Russia, Mexico and Mars, in West Shirley's Eclipse (1986) with Western Europe, and in Greg Bear's Blood Music (1985) with much more global or even cosmic venues. 
William Gibson did not limit himself with the literary works, he also worked in various cyberpunk film projects. He writes the film script of his own literary work, Johnny Mnemonic which was directed by Robert Longo. In addition, the short story Burning Chrome, where all the people and cases are accustomed to the Gibson universe, such as high-tech, radioactive proteins, geneticists, information spies, was adapted by Abel Ferrara with the title, New Rose Hotel, in 1998. Furthermore, Mark Neale made a documentary film on William Gibson and Bruce Sterling entitled No Maps for These Territories in 2000.

The other pioneering figure of cyberpunk science fiction is Bruce Sterling. Sterling, along with Gibson, made significant contributions to the genre. If Gibson gives cyberpunk a philosophical dimension, Sterling systematized this new genre and has become and ideological figure. ${ }^{4}$ It can be said that the contribution of Bruce Sterling is more concentrated on the point of cyberpunk's ideological and systematic defence. If we use Tom Maddox's, the other pioneering writers working together with Gibson, expression, "If Gibson's success provided the motor, Sterling's polemical intensity provided the driving wheel" (Maddox, 2021). The contribution of Bruce Sterling to cyberpunk gains the prominence in Mirrorshades. This is an anthology book and edited by Sterling. In this work, Sterling tried to define, programmatize and provide a holistic framework of cyberpunk literature. William Gibson, Rudy Rucker, Pat Cadigan, and Tom Maddox's short stories, which reflect the general characteristic features of the genre, were collected in this anthology.

Sterling (1998, p. 4) in his introduction to Mirrorshades defines cyberpunk as the mixture of mythical and techno-social policies. According to Sterling, cyberpunk has a structure that combines all types and opens to each area. To him, cyberpunk is a genre that is trying to present an integral topography of the world using unique means and methods.

These means and methods can be both mythical images and visual materials specific to different time and venues. The basic thesis of the cyberpunk science fiction maintains its weight in its essence to reach the extreme sophistication of technology and to threaten the person. According to Sterling, the reality in which we live has a view that feeds a deep anxiety and fear (Hollinger, 1993, p. 208-209). Therefore, the future in his work is presented with an intense dystopian background. He writes that it will be impossible for human to protect his own freedom and uniqueness in the future (Hollinger, 1993, p. 208).

The "picturesque epic" (Hollinger, 1993, p. 208), Schismatrix is based on two rival universe's (Shapers and Mechanists) stories in the same solar system of $23^{\text {rd }}$ century. In the story, 'Shapers' have a kind of genetics and psychology. 'Mechanists' are artificial people (cyborgs) formed from computer and artificial body parts. Both types are presented as if they are the inevitable result of human history. This result, to Sterling, is associated with the decisive role of technological factor in the historical development of human being. A challenging and unending battle for capturing total sovereignty and power among 'Shapers' and 'Mechanists' in the universe is experienced.

\footnotetext{
$4 \mathrm{He}$ is called "President" by other pioneers of cyberpunk. See. John Shirley (2021); "Bruce Sterling", http://en.wikipedia.org/wiki/Bruce_Sterling, 18 January 2021.
} 
Although the book, which consists of five stories, deals with the interaction between technology and human being in a similar framework as pre-cyberpunk writers (F. K. Dick, T. Pynchon, et al.), the intensity of the metaphorical language used in this work has a more advanced framework than the previous examples (Maddox, 1993, p. 326). As Scott Bukatman (2021) correctly points out, although the philosophical depth and stylistic mastery may seem less intense compared to Gibson, the style used in this work pushes his talent to the highest limits.

The distinctive style of Schismatrix had a significant impact on subsequent cyberpunk stories. ${ }^{5}$ Anxiety and fear of the future, dystopia, and technophobia, which are intensely present in Sterling oeuvre, appear in almost all cyberpunk products. It is the rationality of the technology itself that leads to such a view, as I mentioned above. Technology, in Sterling's works and all the cyberpunk sci-fi genre, has, in the final analysis, led to a human-computer symbiosis, posing a species-wide threat to man.

Sterling uses extensive technological jargon to reflect the technological character of the present time. This intense jargon indirectly reflects both the radical changes in the cultural field and the mental and moral position of the man within these changes. In Sterling's work a metaphorical language is developed based on significant technological rationality and constant binary oppositions, such as consciousness-unconsciousness, physical-factual (phenomenal) reality, life-death, body-human, and future-present. Thus, it is possible to read Sterling both as a postmodern collage and bricolage artist and as the "Ezra Pound of cyberpunk science fiction literature" (Maddox, 1993, p. 234).

Postmodern writers, artists and directors offer a very effective framework for describing contemporary world. What they offer in the face of actual reality separates them from modernists. If the nightmarish portrayal of reality obliterates the image of the future (the dystopian background of cyberpunk science fiction), what remains is schizoid individuals and their nihilistic experiences. Vattimo (1988, p. 33, 40-41) has demonstrated that there are powerful parallel points between technology and its rationality, the end of humanism and the rise of nihilism. However, as I partly discussed above, one of the most important features of modernist fiction was that it could still be utopian, despite all the negativities in real life.

The postmodern aspect of Sterling's style is most clearly seen in one of his last works, the Zeitgeist (Sterling, 2000). In this story, a group called "Spice Girls", goes on tour to the Middle East. At the end of this journey, they realize how fragmented the world is and how it is spread over a vast area that cannot be reduced to a single 'narrative'. According to the message of the novel, the narrative of our time is multi-layered and covers a wide variety of aspects. It is not possible to reduce it to a single narrative, especially to a utopian one, as Jameson tirelessly stresses it in his works. In this perspective, the only thing that can be possible is deconstruction, to resolve each different narrative in its own way. This postmodern orientation brings a space security expert to a compromise with the American government to combat terrorism in the aftermath of the 9/11 attacks in The Zenith Angel (Sterling, 2005).

\footnotetext{
${ }^{5}$ Maddox (1993, p. 326) states that this influence is concentrated in the following points: "Fictional intensity used to reflect the conflict; fantasy phenomenon masterfully fed into this density; describing the 'Mechanist/Shaper' universes in all their concreteness and dynamism and reflecting the higher evolutionary processes."
} 


\section{DYSTOPIAN BACKGROUND}

If the world we live in is an indefinite, paranoid appearance, the future perspective will also be affected. Now, the dystopian designs replace the utopian futures, the future is reduced to an apocalyptic scenario only: Actual reality resembles a pre-dormant state of the future. Future, in cyberpunk science fiction cinema, is presented with pessimistic or negative views. Therefore, cyberpunk science fiction, never includes utopian future perspectives; the future is characterised with the dystopic qualities. The most significant feature of cyberpunk science fiction is one of the most important points of the other science fiction, has a dystopian background. What shaped this dystopian stance is that technology is to reach the extreme sophistication level and reflect the fears and dilemmas of individuals of the current times.

Dystopias often project the fears of the present into the future and their themes (uncontrolled companies, unreliable leaders, legitimacy crisis, escalation in crime, etc.) often encode the anxieties that characterize a deep crisis, the crisis of humanity. This kind of atmosphere is always at the forefront in all the prominent products of cyberpunk science fiction cinema. In such films, a constant connection is made between technological overdevelopment and social or human decline. According to this ethos, the world is dominated by giant multinational capitalist corporations and military forces. These institutions, guided by capitalist rationality, are dragging the world and humanity towards a total collapse. Doomsday scenarios of the future are the phenomena that we constantly encounter in such films. If this is the dark, gloomy atmosphere of 2019 Los Angeles in Blade Runner, it is the simulative universe where disappeared reality is declared, due to technological over-development in the Matrix series. A technological overly developed society, where human relations become controversial, cannot exist without human-like androids or 'cyborgs'. Here, we encounter the negative consequences of advanced technology with either human-like androids (cyborgs), or in the form of half-in-androids form, as in Terminator 2 and 3, in which human beings has presented us as the perfect unification with the machine.

Androids, or creatures formed from the human-machine merger, cyborgs, holograms, artificial intelligence, are accustomed to this dystopian universe. Bukatman (1995, p. 203) has noted that such films, like Videodrome, The Fly, etc. change the dichotomic structure between the mind and the body and turn this dichotomic structure into a trichotomic (triple opposition) structure. According to this trichotomic structure, in addition to the mind and body, a third phenomenon, the 'machine', comes into play and a new structure consisting of the mind-body-machine trio emerges. Cyberpunk science fiction movies take this trichotomic structure as their basic starting point, and the narratives are built on this opposition mechanism.

The world, which emerged because of the technological developments shaped by multinational giant capitalist companies and military organisations, in cyberpunk science fiction cinema resembles a post-apocalyptic situation, a desert where the possibilities of future, imagination of humanity about it seem completely exhausted. In such an apocalyptic desert, as Lawrence Person (2001) stated, cyberpunk interprets each technological phenomenon that will occur in the future as a reflection of mere exhaustion and does not attribute it much importance. Because, according to cyberpunk perspective, each technological progress should be evaluated with the effects left on daily life. In this new state of the 
world, cosmic surgeries, nuclear and biological weapons, advanced genetic engineering, 'hackers, artificial intelligences, etc. become important. In such a socio-cultural reality, in such a technological rationality, cyberpunk's techno-guerrillas ${ }^{6}$, like Johnny Mnemonic must empty the basic memories of his childhood in order to carry hidden confidential information in his brain, Neo lands to the desert of real, to the simulative reality to which no other enough brave to descend.

In view of the desert of this world, as Connor (1997, p. 183) emphasizes, both fear and oddity are in question. Such films feed and use both the fear and oddity and make the spectacle forward. The market relations direct these films, and they build reified capitalist futures in the final analysis.

Darko Suvin evaluates the type of science fiction as the top phase of cognitive alienation (McHale, 1993, p. 59). Alienation in cognitive plane also refers to the reality we have been in. The spirit of the present time (zeitgeist) hits its stamp on all conversion forms. Therefore, the dystopic designs regarding the future should be associated with the ideology of the present (Csicserry-Ronay,1993, p. 186). Such films indicate that the ideology of capitalism, which evaluates everything according to capitalist rationality and productivity criteria, has entered a collapse period in field of cultural imagination. The dystrophic nature of the cyberpunk science fiction indicates that the culture-filled by the late capitalist rationality is no longer allows open-utopian texts (Penley, 1995, p. 116).

As the socio-cultural field closes itself to the libertarian perspectives, and as this closure ignores the demands for the future, every meaningful artistic text on the future within this grand closure begins to reflect a 'future anxiety' (Penley, 1995, p. 116). This anxiety status is the product of a mind that cannot construct criticism in a historical perspective. A look that focuses on only the present and approaches the future within such a perspective inevitably loses the fact that the historical is determinant.

Utopia, nevertheless, becomes meaningful with temporal and historical categories. However, in the period in which we live, the dominant tendency that we experience is that the sense of history disappears. The decline of the temporal and historical categories and imprisonment into the present must be dystopian in the future designs.

When categories become obsolete, remembering turns to loss of memory, even transforms to chains of schizophrenic perceptions, when the categories of tradition and history become the mythification and historicity of the present, a future perspective, a utopian approach to the problems encountered in the present also vanish. In such a situation, the world appears to be related with all its horror after a nuclear disaster (Terminator series); with its virtuality and loss of reality (The Matrix series); with a paranoid anxiety (Johnny Mnemonic); with the battlefield of creatures (Aliens vs. Predator); with an invasion of commodities in the near future of 2019 Los Angeles (Blade Runner). In other words, what such films portray with their dystopian depictions of the future also symbolizes the collapse of the imagination of | 1634 | the culture in which they are produced.

\footnotetext{
${ }^{6}$ Cyberpunks describe themselves as "techno-guerrillas". See, Larry McCaffery (1993a, p. 12).
} 


\section{SOCIETAL AND INDIVIDUAL CHANGES IN THE BACKGROUND: CRITIQUES OF GYÖRGY LUKACS}

Postmodernism could be defined as the sum of certain breaking moments in the historical development of western culture. This theory rejects all kinds of utopias, goals, even meanings, uniqueness, that is, the quality of being genuine; Nor does it have powerful heroes; the characters are schizophrenic rather than neurotic - reflecting the basic psychological mood of modernist characters in the face of terrifying external reality; time does not flow forward, it contains intertwined and often complex time periods; it has no clear message, instead of having nothing to say, aimlessness, deadlock and irony come to the fore. As in modernist texts, it is not the case that the event flows inherently and the characters are chasing a meaning, struggling for a goal or a utopia.

There is a long historical process, breaking points behind the emergence of this type of aesthetics and gaining a distinctive and even dominant character in all fields of art, especially in cinema and painting. These breaking moments could be examined under the following headings: The disappearance of the unifying human imagination, the disintegration of this idea of unity over time, and the closure of individual to his interior, decline of the project of the Enlightenment after the war and nuclear disasters (Hiroshima and Nagasaki experiences) in the 20th century, and the rise of counter-Enlightenment. In the analysis of the first two moments, I would like to base the theses on the famous Hungarian Marxist theorist György Lukacs. His theory deeply influenced the new Marxists, even writers like Adorno, who was close to Marxism but more critical of it.

Starting from Max Weber, Lukacs $(1969,1974)$ argues that the intellect of modern man is fragmented, and he perceives and makes sense of the external reality, that is, the world outside himself, in a split. Lukacs (1974) underlines that art and literature reflect this disintegration. He draws out the experience of "integrated life" of the classical world against the totality of modern disintegrated life experience. At this point, Lukacs brings to the fore the distinction between classic epic and modern epic that reflect this difference. According to him (Lukacs, 1974, p. 28-29), in the classical epic, there is an immanent experience of life and meaning of man who is not divided into "inside" and "outside", the self and the world. Because in classical life experience life and essence are identical. In a kind of narrative (in classical epic) immanent to life, no obstacle, no 'medium' came between human being and his world; there is an individual who touches the world, grasps it in its own integrity, transfers it to his own action, and his real experience. Epic integrity within this structure also requires the 'hero' to influence the outside world, but not to rise above it.

The organic structure of the classical world found its equivalent in the world of forms. In other words, the classical epic was a reflection of the organic world in terms of forms (Lukacs, 1974, p. 32). In the modern era, with the dissolution of this structure, the introduction of artificial cultural factors between man and his world, and the rise of modern literature a new world of forms have emerged.

Lukacs (1969, p. 25-27) argues that contrary to classical epic and classical realism, late-modernist writers like Joyce, Beckett, Kafka, and Proust deal with man with a distorted worldview, cuts him off from his own 'potentials', shuts him down to his inner world, and imprison him to 'an isolated 
subjectivism that has come one after another'. According to these writers, says Lukacs (1969, p. 21, 27), man is innately a solitary, asocial, ahistorical being, unable to relate to other people. He (Lukacs, 1969, p. 21) argues that the late modern literature is constantly built on the basis of the 'inner world', and that the dialectic of hero and 'external reality', which is always considered in balance in the products of both the classical organic epic world and classical realist literature, is deteriorated in favour of the 'hero'. These techniques, according to Lukacs (1969, p. 24), have been translated in late modern texts directly into the constitutive principle that governs the narrative texture and the presentation of characters. Such a dominant character of these techniques must, he argues (Lukacs, 1969, p. 19), be directly related to the author's ideological world, his weltanschauung (worldview). Lukacs (1969, p. 19) underlines that the author's ideological orientation, weltanschauung, relates to the answer given to the fundamental question in literary and aesthetic fields: 'what is human being?' According to him (Lukacs, 1969, p. 19), the author determines his own style and narrative technique with the answer s/he gives to this question and constructs her/his own work through this style and technique, positions her/his characters and heroes accordingly, and makes them speak.

Therefore, according to Lukacs (1969, p. 19-23), if a man is a socio-political being, he must be considered in a balance within the framework of his abstract and concrete potentialities. Abstract potentialities should not be elevated above concrete ones, and concrete potentialities should not be depicted in a nightmare atmosphere of the world. But advanced modern literature, according to Lukacs (1969, p. 21), does just that; it deals with human beings only within the framework of abstract potentialities, describes them, and confines them entirely to the field of subjectivity. This, in fact, is the main reason for the ahistorical feature of the late modern characters we encounter in these works. Because they are not handled within the framework of concrete potentialities, they do not develop, nor do they come into conflict with reality. Instead, they withdraw into themselves, under the influence of a deep sense of 'angst' about the reality that surrounds them. This is where, according to Lukacs (1969, p. 21), withdrawal from reality becomes possible.

Lukacs (1969) states that contemporary art and literature have two main orientations within this context: Fear-anxiety (angst) and chaos. While reality has a chaotic meaning for the writer and the artist, man is reduced to a "bad day of God" trying to find his own way in this chaotic terror, whose beginning and end are uncertain -as in Camus, for example (Lukacs, 1969, p. 25). Reality and realistic detail are considered important (as in Kafka and other late modern writers) to the extent that it expresses the 'ghostly unreality', the 'nightmare world' and ultimately increases fear anxiety. In late modern works, therefore, the characters are in a dull, unrecognizable identity. They were created with an ahistorical attitude, and they appear again with an ahistorical image in the narrative (Lukacs, 1969, p. 21). They have a heavy existential air on them, which exactly coincides with Heidegger's (2008) worldview, the individual-human understanding, which he put forward with his "thrown into being" (Geworfenheit ins Dasein) approach.

The destination of this orientation, according to Lukacs (1969), is a place where, in the end, man as a concept will be eradicated. Because, rising human subjectivity above the objective reality of the environment in which he lives, ignoring the fact that his inner and outer world forms a dialectical whole, 
and focusing only on his subjective potentialities ultimately brings the collapse of the concept of 'human being'. In late modern works the disintegration of personality, according to Lukacs (1969, p. 25), is matched by the disintegration of the outer world:

"Attenuation of reality and dissolution of personality are thus interdependent: the stronger the one, the stronger the other. Underlying both is the lack of a consistent view of human nature. Man is reduced to a sequence of unrelated experiential fragments: he is inexplicable to others as to himself." (Lukacs, 1969, p. 26).

There is not much difference between the period in which Lukacs put forward these views and the era when cyberpunk was on the rise (Lukacs' The Meaning of Contemporary Realism was first published in 1957). Therefore, a parallelism can be drawn between the worldview of canonical writers of modernism like Kafka, Proust and Müsil, whom Lukacs calls as 'late modern' and heavily criticize, and the worldview created in cyberpunk literature. In other words, Lukacs' theses can also be used to examine this subgenre, cyberpunk science fiction. Here too (in the context that Lukacs criticizes) highly controversial characters and perspectives on the world appear. In this sub-genre we encounter nihilistic, ahistorical, introverted characters, withdrawn from the outer world, narratives that only say and explain that the world is a 'bad day of God'. In this literature, characters are passive or pseudo- heroes because they are not created in their own potentiality, from a historical perspective. The narratives in this genre were created by plundering the previous narratives on the aesthetic plane and adapting them to the new techno jargon. A whole world of technology comes to us in apparent deception: In criticizing, technological rationality is intrinsically affirmed. Special effects here have a fundamental decisive function. Such effects, as Jameson (1991, p. 384) noted constitute a kind of crude and emblematic caricature of the deeper logic of all contemporary image production. The 'expensive' form replaces the older 'significant' form; It becomes the valid motto in this universe of commodities, where exchangevalue constitutes itself a commodity in a complex complementary spiral.

Does cyberpunk really criticize technology, or is it indirectly, internally, glorifying it? This situation becomes more ideological and problematic especially for cyberpunk science fiction literary and cinematic works. Fredric Jameson (1991, p. 383) emphasizes that although such films have a critical perspective on the drift of society towards technological determination, the main fact they want to show, and present is the triumph of technology and its rationality.

By giving technology a fascination, a mythical quality these productions underlying current technological rationality. They both have a dystopian future, a vision, and are paranoid and pessimistic about the extent that technology has reached and present these technologies to us with a morbid fascination. The technologies used in such film productions, as Jameson points out (1991, p. 384) are advanced technologies that can represent these technologies as the technologies of the collapsing period. The visions that approach these advanced technologies and their imagination, this technological overdevelopment from a technical perspective, approach it even more because they use the language and terminology of the machine they criticize. It is not the deep critique of the technological civilisation that the Terminator series, for instance, exalts, but the advanced technological appearance of "Skynet" and the spectacle of this technology. "I'll be back", which is said in the final sequence of the film, is both the 
triumph of technological rationality and a method of guaranteeing that other films in the series can be prepared and presented to consumption. The spectacle thus becomes a phenomenon to be used in this context. Unstoppable devastation, clashes, massacres, and armed struggles, as the immediate expressions of this logic of spectacle, saturate the demands of the market mechanisms and become an essential tool for the film's success.

\section{Conclusion}

The Enlightenment movement began to be questioned, especially since the 1960s. Within this framework, the most programmatic criticism was developed by postmodern theorists, and they characterized the new era as a 'postmodern' era, mostly formed because of the Enlightenment or the transformations that took place within modernism itself. According to them, 'postmodernism' was not considered as a temporal category, an afterthought, but as a process occurring within modernism itself.

However, against these ideas, whose voice began to dominate in a short time, criticism began to be brought against these ideas, starting from the first half of the 1980s, and the thesis that the Enlightenment was an unfinished project and that the world needed Enlightenment utopias was persistently defended. The countercriticisms against postmodernism focused on the following points: All the goals of the Enlightenment have not yet been realized, some negative situations that have emerged over time can only be a distorted view of the Enlightenment, therefore this great project and its main goals, a more just world, an egalitarian society and upholding the goals of the creation of a free human being should be defended.

On the other hand, it should be underlined that postmodern criticism, while saying that nothing meaningful can be built and that people must continue their lives in an uncertain reality where meaning itself is divided, literally points to the tragic dimension of the point reached. Sharp observations on the tragic aspects of the new life encountered in most postmodern thinkers have also been expressed by antipostmodern theorists such as Fredric Jameson, David Harvey, Steven Connor, Steven Best \& Douglas Kellner (1991). However, the point that becomes problematic here is the fact that reality, which is described by postmodern theorists with all its appearances, is, in the final analysis, justified and presented: While life is reflected with all its nightmare appearances, there is little effort that can be made to change it. The utopias that would be developed to overcome the nightmare reality in question do not matter either. Therefore, according to the postmodern thinkers (here, first, Lyotard (1984) should be remembered), there can no longer be any great ideals. More provocative and thought-provoking, according to these postmodern theorists, is the view that the ideals of the Enlightenment or of modernism can ultimately lead to fascism, a view that eventually imprisons these thinkers in the life they criticize. At this point, when we look at the areas where postmodern aesthetics are structured and justified, a literary aesthetic field comes to the fore: Cyberpunk science fiction. Postmodern thought, at least in terms of aesthetics, appears with intense use in this field. Cyberpunk Science fiction reflects the main lines of postmodern thought. The determining factor of this thought is the intensive use of technology. However, this heavy use of technology is carried out in a pessimistic framework, on a plane where science and technology are criticized in appearance. 
Two formidable figures in this literary-aesthetic field are William Gibson and Bruce Sterling. In these writers' works, where science and technology are used with a critical tone, the future is envisioned in a very bad and pessimistic way. Their works include reflections and assumptions about the futureand many of these assumptions, as explained above, seem critical., even if these assumptions are true, that doesn't mean they can necessarily be true. However, what such literary figures and works really give us to consume is not these incredible prognoses and dystopian meteorological bulletins, but rather the technology itself, with its special effects. Criticisms of these authors and works dissolve into affirmative character of these special effects. The human-machine boundary blurs in these effects and the resulting 'product' is either a human-like creature armed with technology, or a kind of digital human being perfectly integrated with it.

The battle between existence and extinction are the forms of representation that most characterize postmodern technological use. In the postmodern cyberpunk aesthetic, technology is often reflected in the relationship between fragmentation-creation and re-creation. In contrast, in the science fiction forms of modernism, as Jameson (1991, p. 387) points out, there was a kind of hidden mythical obsession with a secret pleasure mechanism related to the creating machine. This fascination, the secret mythical pleasure mechanism arising from this act of creation, turns into a struggle for existence and destruction in postmodern cyberpunk science fiction. Pleasure also arises from this aesthetic of destruction. It is a parable of how, in the age of mechanical reproduction, a work of art looks in morbid fascination with its alienated power. The postmodern, however, has reached a level beyond this: unlike the modern's delight in the phantasy of the miracle-working machine, the postmodern's delight in the disintegration of the machine at this critical point is largely misunderstood if we do not realize that this is exactly how postmodern technology consumes and celebrates technology. The aesthetic of destruction is an aesthetic that is formed with the continuous use of technology, and this aesthetic abstracts it from the social and gives it a mythical dimension. This technological mythicism is a myth system provided with stylistic innovations and visual effects, and it overlaps with power, which is a necessary element of ideology.

"Domination has its own means and methods" writes Herbert Marcuse (1991, p.64). The dominance continues even when the 'meaningful' form is replaced by 'expensive' form and 'special effects'. All these forms, these special effects, and a whole world of advanced technology, with their vision of the world, justify existing relations of domination in the system, give them legitimacy, and make the late capitalist system more bearable with the imaginary universes they present. The real view, the undistorted view of the world of advanced technology in which they exist and which they associate with social transformation, may become possible in a place where all computers are inoperable. Thus, imaginary journeys belong to this universe itself, the universe characterized by social decadence: they both reflect and distort it.

All these works are writers, and postmodern thought and aesthetics itself cannot be understood without approaching the adventure of man in the historical process from a historical perspective. The dissolution of the integrated world view, which Lukacs underlines in almost all of his works, has brought along the human crisis. We cannot separate the products of the postmodern cyberpunk literature from this crisis. In this respect, the humanitarian crisis that we encounter today, especially in this literature, 
actually has a history. The starting point of the crisis is the 19th century. The period when this crisis became evident was the second half of the 19th century, and the period when it was well understood was the 20th century. Writers such as Kafka, Joyce, Müsil, Proust, Becketts whom Lukacs criticizes as 'contemporary realist', only advanced the crisis styles of the 19th century, favoured by romantics and symbolists such as Baudelaire, Mallarme, and Edgar Allan Poe. Postmodernism and cyberpunk science fiction gave us extreme examples of this style. Thus, they should be approached in such a historical perspective that centres on the crisis of human being.

\section{Ethics Committee Permission}

This article is not part of a working group that requires ethical committee approval.

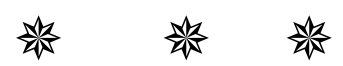




\section{References}

Bear, G. (1985). Blood music. Arbor House.

Best, S., \& Kellner, D. (1991). Postmodern theory: Critical interrogations. The Guilford Press.

Bethke, B. (2021a, January 11). Cyberpunk - A short story by Bruce Bethke. http://www.infinityplus.co.uk/stories/cpunk.htm

Bethke, B. (2021b, January 15). Cyberpunk. http://en.wikipedia.org/wiki/Cyberpunk

Bukatman, S. (1995). Who programs you? The science fiction of the spectacle. In A. Kuhn (Ed.). Alien zone-Cultural theory and contemporary science fiction cinema. Verso.

Bukatman, S. (2021, May 16). Postcards from the posthuman solar system. http://www.depauw.edu/sfs/backissues/55/bukatman55art.htm

Connor, S. (1997). Postmodernist culture: An introduction to theories of the contemporary (2ndEdition). Blackwell Publishers.

Csicserry-Ronay, I. (1993). Cyberpunk and neoromanticism. In L. McCaffery (Ed.). Storming the reality studio -A casebook of cyberpunk and postmodern science fiction. Duke University Press.

Dick, P. K. (1999). Do androids dream of electric sheep. Millennium.

Gibson, W. (1986). Count zero. Arbor House

Gibson, W. (1988). Monalisa overdrive. Bantham.

Gibson, W. (1993). Neuromancer. Harper Collins Publisher.

Habermas, J. (1987). Modernity: An incomplete project. In H. Foster (Ed.). The anti aesthetic: Essays on postmodern culture. Bay Press.

Harvey, D. (1992). The condition of postmodernity: An enquiry into the origins of cultural change. Blackwell.

Hassan, I. (1983). The dismemberment of orpheus: Towards a postmodern literature. University of Wisconsin Press.

Heidegger, M. (2008). Being and time (Trans. J. Macquarie \& E. Robinson). Harper Perennial Modern Thought.

Hollinger, V. (1993). Cybernetic deconstructions: Cyberpunk and postmodernism. In L. McCaffery (Ed.). Storming the reality studio $-A$ casebook of cyberpunk and postmodern science fiction. Duke University Press.

Jameson, F. (1974). The prison-house of language: A critical account of structuralism and Russian formalism. Princeton University Press.

Jameson, F. (1991). Postmodernism, or, the cultural logic of late capitalism. Duke University Press.

Jameson, F. (1998). The cultural turn: Selected writings on the postmodern 1983-1998. Verso.

Kadrey, R., \& McCaffery, L. (1993). Cyberpunk 101: A schematic guide to. In L. McCaffery (Ed.). Storming the reality studio $-A$ casebook of cyberpunk and postmodern science fiction. Duke University Press.

Leary, T. (1993). The Cyberpunk: The individual as reality pilot. In L. McCaffery (Ed.). Storming the reality studio-A casebook of cyberpunk and postmodern science fiction. Duke University Press. 
Lukacs, G. (1969). The meaning of contemporary realism. Merlin Press.

Lukacs, G. (1974). Theory of the novel. The MIT Press.

Lyotard, J. F. (1984). The postmodern condition: A report on knowledge. Manchester University Press.

Maddox, T. (2021, January 18). After the deluge: Cyberpunk in the '80s and '90s. http://project.cyberpunk.ru/idb/cyberpunk_in_80-90.html

Mandel, E. (1980). Late capitalism. (Trans. J. De Bres). Verso.

Marcuse, H. (1991). One dimensional man: Studies in the ideology of advanced industrial society (2 ${ }^{\text {nd }}$ Edition). Routledge.

McCaffery, L. (1993a). Introduction: The desert of the real. In L. McCaffery (Ed.). Storming the reality studio - A casebook of cyberpunk and postmodern science fiction. Duke University Press.

McCaffery, L. (1993b). An interview with William Gibson. In L. McCaffery (Ed.). Storming the reality studio -A casebook of cyberpunk and postmodern science fiction. Duke University Press.

McHale, B. (1993). POSTcyberMODERNpunkISM. In L. McCaffery (Ed.). Storming the reality studio $-A$ casebook of cyberpunk and postmodern science fiction. Duke University Press.

Penley, C. (1995). Time travel, primal scene and the critical dystopia. In A. Kuhn (Ed.). Alien zone cultural theory and contemporary science fiction cinema. Verso.

Person, L. (2021, May 14). Notes toward a Postcyberpunk manifesto. https://www.scribd.com/document/463211695/Notes-Toward-a-Postcyberpunk-Manifesto

Shiner, L. (1984). Frontera. Baen.

Shirley, J. (1986). Eclipse. Methuen.

Shirley, J. (2021, January 18). Two Cyberpunks: Sterling \& Rucker. http://www.darkeche.com/JohnShirley/sterling.html

Sterling, B. (1985). Schismatrix. Arbor House.

Sterling, B. (2000). Zeitgeist. Bantham Books.

Sterling, B. (2005). The Zenith angel. Del Rey.

Sterling, B. (2021, January 15). Cyberpunk in the nineties. http://www.streettech.com/bcp/BCPtext/Manifestos/CPInThe90s.html

Suvin, D. (1993). On Gibson and Cyberpunk SF. In L. McCaffery (Ed.). Storming the reality studio $-A$ casebook of cyberpunk and postmodern science fiction. Duke University Press.

Vattimo, G. (1988). The end of modernity -Nihilism and Hermeneutics in postmodern culture (Trans. J. R. Snyder). Polity Press.

Wikipedia (2021, January 18). Bruce Sterling. http://en.wikipedia.org/wiki/Bruce_Sterling

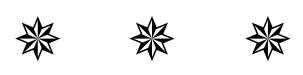

